\title{
To the question of peculiarities of thermal activation of natural siliceous raw material
}

\author{
Natalya Chumachenko ${ }^{1,{ }^{*}}$, Diana Galiullina ${ }^{1}$, and Euphym Mironenko ${ }^{2}$ \\ ${ }^{1}$ Samara State Technical University, Institute of Architecture and Civil Engineering, \\ 194, Molodogvardeyskaya St., 443001, Samara, Russia \\ ${ }^{2}$ CJSC «TechStroyProekt», 146, Samarskaya St., 443010, Samara, Russia
}

\begin{abstract}
The results of research of activity enhancement of natural siliceous raw material are given in the article. Fossil meal of Khotynetsky deposit, diatomite of Sharlovsky deposit, silica clay of Balasheika deposit were used as natural active mineral admixtures. The influence of heattreating temperature and dispersion on activity of different types of siliceous raw material is studied. The increase of activity of fixation of $\mathrm{Ca}(\mathrm{OH})_{2}$ in several times is traced after heat-treating at a certain temperature in the range from 100 to $800{ }^{\circ} \mathrm{C}$. The type of activity change is discovered. Explanation is given connected with the change of silica structure in the surface layer. Parameters of the highest activity are defined for every type of siliceous raw material.
\end{abstract}

\section{Introduction}

In the structure of many cementing, first of all portland pozzolan cement and limestone pozzolan cementing concretes are present active mineral admixtures (AMA) [1 - 3].

When maturing AMA adsorb at first, and then chemically fix $\mathrm{Ca}(\mathrm{OH}) 2$, received from interaction of alite with water into solventless hydrated calcium silicate according to reaction:

$$
\mathrm{mCa}(\mathrm{OH})_{2}+\mathrm{SiO}_{2} \text { (act.) }+\mathrm{nH}_{2} \mathrm{O} \rightarrow(0,8-1,5) \mathrm{CaO} \cdot \mathrm{SiO}_{2} \cdot \mathrm{pH}_{2} \mathrm{O}
$$

This process happens under usual conditions of cementing: moist environment with positive temperatures. The amount of AMA in the structure of cementing depends on mineral composition of cementing and activity of the admixture. Activity of AMA is determined via fix of $\mathrm{Ca}(\mathrm{OH})_{2}$.

The activity amounts of different admixtures of natural and artificial origin which are given in table 1 are known.

As it is seen from table 1 the highest activity is with silica wastes, and from natural ones with natural siliceous raw material.

The siliceous raw material is used widely in the structure of airbinding [4] concretes [5, 6], in the materials of construction-related use [7].

\footnotetext{
${ }^{*}$ Corresponding author: uvarovang@mail.ru
} 
Table 1. Activity of admixtures.

\begin{tabular}{|c|c|c|}
\hline \multirow{2}{*}{ Group of admixtures } & Name of admixtures & $\begin{array}{c}\text { Activity of admixture on soaking } \\
\text { of lime, lime-stone mortar during } \\
\mathbf{3 0} \text { days, in mm CaO on 1 } \mathbf{g} \text { of } \\
\text { admixture, not less }\end{array}$ \\
\hline $\begin{array}{c}\text { Natural admixtures of } \\
\text { sedimentary origin }\end{array}$ & $\begin{array}{c}\text { Diatomites, fossil meals, } \\
\text { silica clays }\end{array}$ & 150 \\
\cline { 2 - 3 } & Burnt clays & 30 \\
\hline \multirow{2}{*}{$\begin{array}{c}\text { Natural volcanogenic } \\
\text { admixtures }\end{array}$} & $\begin{array}{c}\text { Ashes, pumice-stones, } \\
\text { pozzolans }\end{array}$ & 50 \\
\cline { 2 - 3 } & Trasses & 60 \\
\hline \multirow{2}{*}{ Artificial admixtures } & Silica waste & 200 \\
\cline { 2 - 3 } & $\begin{array}{c}\text { Burnt clay, furnace } \\
\text { bottom ashes and slags }\end{array}$ & 50 \\
\hline
\end{tabular}

The efficiency of admixtures of natural and industrial raw material can increase due to mechanochemical activation [8] and thermal activation [9 -11].

Taking into consideration the spread of natural siliceous raw material and resourcesaving approach to the raw-material base of construction industry [12] a goal was set: to study the influence of heat-treating temperature on activity of natural siliceous raw material of different dispersion.

\section{Research material}

As natural active mineral admixtures (AMA) were applied: fossil meal of Khotynetsky deposit, diatomite of Sharlovsky deposit, silica clay of Balasheika deposit. Chemical structures of silica raw material are presented in table 2 .

Table 2. Chemical structure of silica raw material.

\begin{tabular}{|c|c|c|c|c|c|c|c|}
\hline \multirow{2}{*}{$\begin{array}{c}\text { Type of silica } \\
\text { material }\end{array}$} & \multicolumn{7}{|c|}{ Oxide content, mass. \% } \\
\cline { 2 - 8 } & $\mathbf{S i O}_{\mathbf{2}}$ & $\mathbf{A l}_{\mathbf{2}} \mathbf{O}_{\mathbf{3}}$ & $\mathbf{F e}_{\mathbf{2}} \mathbf{O}_{\mathbf{3}}$ & $\mathbf{C a O}$ & $\mathbf{M g O}$ & $\mathbf{R}_{\mathbf{2}} \mathbf{O}$ & Polypropylene \\
\hline Silica clay & 82,0 & 4,6 & 2,8 & 0,6 & 1,5 & 4,3 & 4,2 \\
\hline Diatomite & 76,0 & 6,0 & 3,3 & 0,4 & 2,7 & 3,2 & 8,4 \\
\hline Fossil meal & 56,0 & 14,8 & 8,6 & 1,6 & 2,8 & 4,5 & 11,7 \\
\hline
\end{tabular}

Characteristics of silica raw material are studied well enough [13 -14].

\section{Methods}

In the research two methods were used: method of thermal activation and method of activity determination.

Method of thermal activation lies in change of activity due to heat-treating. Activity of AMA is determined first of all by the origin of admixture (table 1). At the same time initial activity can be changed by heat-treating. This is the so called thermal activation effect [15].

With the aim of activity enhancement of natural siliceous raw material was studied the effect of thermal activation which is mentioned in literature. The research was held with natural siliceous raw material.

Method of activity determination: after heat-treating activity was determined on the basis of limestone soaking from limestone mortar in $\mathrm{mg} \mathrm{CaO}$ on $1 \mathrm{~g}$ of admixture. 


\section{Experiment}

To determine the temperature of regional activation of silica containing AMA they were subject to heat-treating under temperatures from 100 to $800{ }^{\circ} \mathrm{C}$ with the interval in $100{ }^{\circ} \mathrm{C}$.

The experiment was conducted parallel on silica raw material of three types of dispersion:

1 - with particle size of $0,3-1,0 \mathrm{~mm}$;

2 - with particle size less than $0,3 \mathrm{~mm}(100 \%$ undersize $0,3 \mathrm{~mm})$;

3 - with particle size less than 80 micron ( $100 \%$ undersize $0,08 \mathrm{~mm}$ ).

After heat-treating of silica raw material of a certain dispersion their fixation activity of $\mathrm{Ca}(\mathrm{OH})_{2}$ was determined.

\section{Experiment results}

The results are given in figure 1 . The initial activity of raw material is different and changes with dispersion. For large particles of 0,3-1,0 mm, when natural dispersion is saved the highest activity was with diatomite and fossil meal as more permeable rocks. When regrounding the raw material till $100 \%$ undersize $0,3 \mathrm{~mm}$ the activity falls which is explained with the erosion of initial permeable structure, decrease of specific surface. Further grounding (till $100 \%$ undersize $0,08 \mathrm{~mm}$ ) enables activity enhancement proportionally to the initial rock density.

The most essential activity enhancement due to heat-treating was reached for diatomite with dispersion $<80$ micron at $\mathrm{t}=200{ }^{\circ} \mathrm{C}$.

\section{Discussion}

Activity dependence on temperature for investigated types and dispersion of silica raw material has a peculiar sinusoidal character and according to Snider's data [15] is explained by the change of structure of silica in the surface layer. On the surface of silica in different proportions can be five types of groups:

- silanol (combination water - free, separate OH-groups);

- physically-combined water - water molecules having hydrogen bonds with silanol groups;

- dehydrated oxide - siloxane groups;

- bigeminal $\mathrm{OH}$ group fixed with one silicon atom;

- reactive vicinal $\mathrm{OH}$ groups prevailing in fine-pored silica - neighbouring, situated nearby OH-groups fixed by hydrogen bond. 


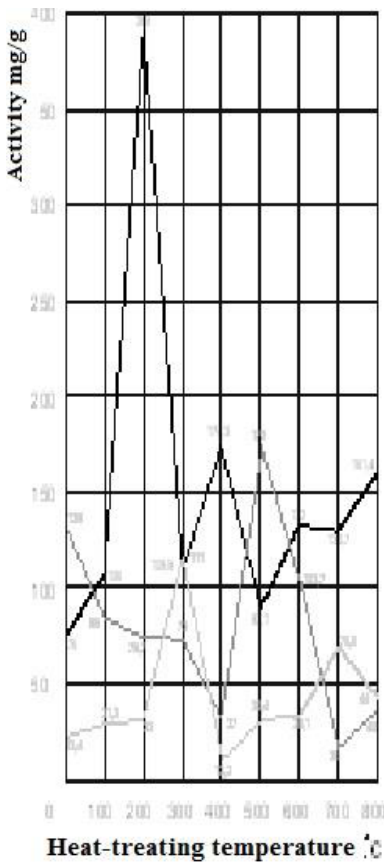

dispersion $0.08 \mathrm{~mm}$

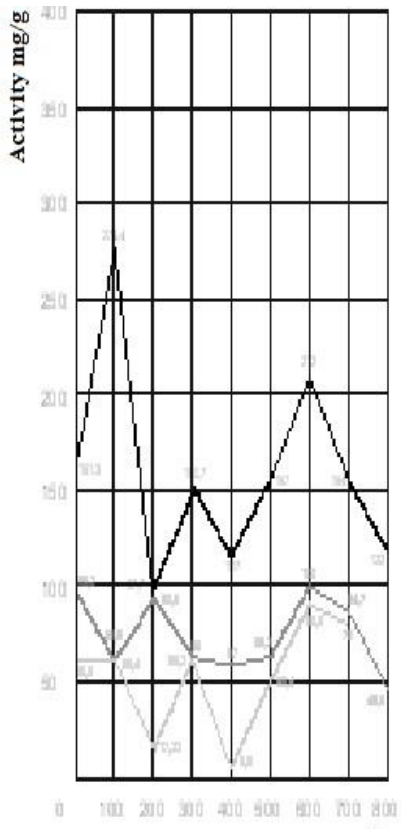

Heat-treating temperature :. $\bar{c}$

Symbols:

dispersion $0.3 \mathrm{~mm}$

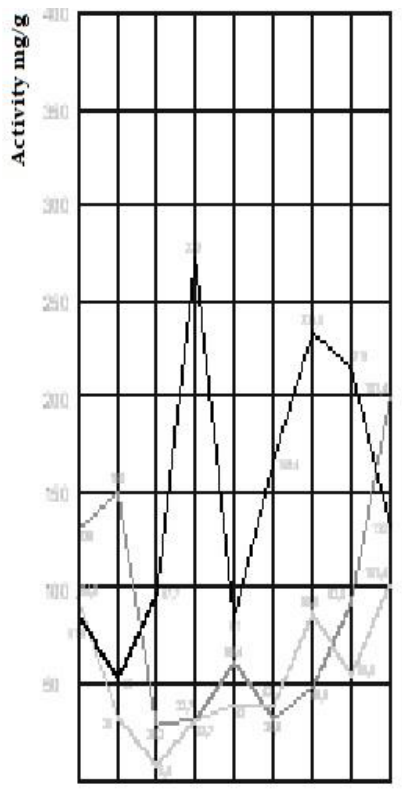

Heat-treating temperature ${ }_{1}^{2} \hat{L}$

dispersion $1.0 \mathrm{~mm}$

Fig. 1. Thermal activation of natural natural siliceous AMA.

Under heating silica first of all physically-combined water is removed. If temperature increases silanol groups are able to condensate making thus siloxane groups. As a result the material gets water-repellent property and consequently the lowest chemical activity. The highest chemical activity have reactive vicinal groups.

Though the research [15] has found that to differentiate these processes is not possible as they can occur simultaneously, but explain the received results. Maximum activity at low temperatures $\left(100-350{ }^{\circ} \mathrm{C}\right)$ is connected with removal of physically-combined water, at high temperatures - with the creation of reactive groups. Minimal activity is explained by creation of siloxane groups.

\section{Use of the experiment results}

Diatomite of the highest activity received with heat-treating of finely dispersed diatomite $(<$ 80 micron) at $\mathrm{t}=200{ }^{\circ} \mathrm{C}$ was used in the structure of cementing of masonry mortar which guarantees absence of efflorescence from $\mathrm{Ca}(\mathrm{OH})_{2}[16]$.

\section{Conclusions}

1. Original and artificial active mineral admixtures generally made of amorphous silica $\left(\mathrm{SiO}_{2}\right.$ more than $\left.50 \%\right)$ is widely used in the structures of cementing, mortars and concretes. AMA adds to the reduce cement consumption and enhances corrosive resistance of hardened cement paste.

2. Is defined thermal activation after heat-treating within temperature range from 100 up to $800{ }^{\circ} \mathrm{C}$ of natural siliceous raw material: diatomite, silica clays, fossil meal. 
3. It is found out that the activity amount is influenced by the type of raw material, heatheating temperature and dispersion.

4. Dependence activity on temperature has a sinusoidal character and is explained by change of silica structure.

\section{References}

1. GOST P 56592 Mineral admixtures for concretes and water mortar. General technical conditions (2015)

2. U.G. Ivashenko, N.A. Kozlov, D.K. Timokhin, Vestnik of Saratov State Technical University 3, 25-29 (2010)

3. U.M. Bazhenov, V.S. Demyanova, V.I. Kalashnickov. Modified high-quality concretes, 368 (Publishing house of Association of Universities of Building and Construction, Moscow, 2006)

4. T.U. Saphonova, Izvestia of St.Petersburg Railroad University 2(31), 93-98 (2012)

5. E.G. Matveeva, Concrete efficiency enhancement by admixture of nanodispersed silica: dissertation ... candidate degree in technology : 05.23.05 ( Belgorod, 2011)

6. V.I. Cherkashin, B.D. Toturbiev, V.Y. Matsapulin, Concrete and armed concrete 6, 2-5 (2013)

7. S.F. Koren'kova, U.V. Sidorenko, Achievements of modern natural sciences 3, 172 (2014)

8. V.P. Suchkov, Urban Construction and Architecture 4, 82-86 (2011) DOI: $10.17673 /$ Vestnik.2011.04.16

9. E.I. Evtushenko, Management of structure and formation of building materials with the use of raw material thermal activation : dissertation ... candidate degree in technology: 05.23.05 (Belgorod, 2005)

10. I.N. Anisina, A.G. Chetverikova, O.N. Kanugina, Vestnik of OSU 4(140), 170-174 (2012)

11. O.N. Kanugina, A.G. Chetverikova, Study of materials 6, 44-49 (2011)

12. N.G. Chumachenko, Urban Construction and Architecture 1, 112-116 (2011) DOI: $10.17673 /$ Vestnik.2011.01.22

13. N.G. Chumachenko, M.N. Baranova, S.F. Koren'kova, Construction materials 8, 1-4 (2011)

14. N.G. Chumachenko, M.N. Baranova, S.F. Koren'kova, Construction materials 12, $72-$ 75 (2012)

15. Modified silica in sorption, catalyse and chromatography, 24-26 (Chemistry, Moscow, 1986)

16. E.V. Mironenko, Physical and chemical processes of efflorescenceformation in brickwork and methods of its elimination : dissertation ... candidate degree in technology: 05.23.05. (Samara, 2006) 